\title{
Zenitistični koncept barbarogenija kot kritika zahodnoevropske kulture
}

\author{
Kristina Pranjić
}

Akademija umetnosti, Univerza v Novi Gorici, Vipavska 13, 3000 Nova Gorica https://orcid.org/0000-0002-2259-7931

kristina.pranjic@ung.si

\begin{abstract}
Članek tematizira podobo balkanskega človeka barbarogenija, kot jo zasnuje eden od osrednjih predstavnikov jugoslovanske avantgarde Ljubomir Micić. Ideji barbara-genija in balkanizacije/barbarizacije Evrope se razvijeta v reviji Zenit, prav tako pa sta zastopaniv Micićevi poeziji in prozi (roman Barbarogenij Decivilizator). Podobne sintagme najdemo tudi pri Srečku Kosovelu in akterjih ljubljanske revije Tank. Le-te kažejo na oblikovanje posebne lokalne identitete, ki vzpostavlja tudi nacionalni kontekst njihovega dela. S tem pa pričajo tudi o izvirni misli in umetnostno-zgodovinski specifiki jugoslovanske avantgardne struje, povezane s specifičnimi družbeno-političnimi dogodki v prvih desetletjih 20. stoletja. Funkcija avantgardističnega vračanja k nacionalnim koreninam je sprevračanje hierarhiziranega razmerja do Zahoda z radikalno avtostereotipizacijo. Tako internacionalizacija/kozmopolitskost kot radikalno izpostavljanje nacionalnih karakteristik se kažeta kot strategiji za transgresijo identitet in vzpostavljanje Balkana kot pluralne kulturne identitete s svojo ustvarjalno močjo znotraj jugoslovanske avantgarde.
\end{abstract}

Ključne besede: jugoslovanska književnost / literarna avantgarda / zenitizem / Micić, Ljubomir / barbarogenij / imagologija / Evropa / Balkan / kulturna identiteta

\section{Koncept barbara-genija $v$ jugoslovanski avantgardi}

Članek tematizira pojem »balkanskega človeka«, pojmovanega kot »barbarogenija «, ki je hkrati »barbar" in "genij". ${ }^{1}$ Oblikovanju takšne podobe balkanskega človeka v jugoslovanski avantgardi lahko sledimo skozi različne številke avantgardistične revije Zenit, ki je izhajala med letoma 1921 in 1926 v Zagrebu in Beogradu pod uredništvom Ljubomirja Micića.

${ }^{1}$ Članek je nastal v okviru raziskovalnega projekta Z6-1882 "Jugoslovanske avantgarde in metropolitanska dada (1916-1927): Večsmerna in transnacionalna genealogija", ki ga financira ARRS. 
Liku barbarogenija, nekakšnemu balkanskemu Zaratustri, je Ljubomir Micić posvetil tudi roman $\mathrm{z}$ naslovom Barbarogenij Decivilizator (Barbarogénie le Décivilisateur), ki je izšel leta 1938 v Parizu. Pred izdajo tega dela lahko pri Miciću najdemo tudi veliko drugih referenc na balkanskega barbarogenija, ki je predstavljen kot protipol dekadentni Evropi, ki jo je treba balkanizirati oziroma decivilizirati.

Barbarska kultura Balkana oziroma kar celotnega slovanskega sveta je v jugoslovanski avantgardi razumljena kot živa sila, dinamizem, ki bo prerodil propadajočo Evropo. Tukaj srečamo znano dihotomijo med kulturo in civilizacijo, pri čemer je socializacija razumljena kot mehaničen pojav, ki zasužnji človeka in onemogoči njegovo ustvarjalnost. Tako je tudi za Micića kultura ali bolje nekakšna barbarska "antikultura", nasprotna civilizaciji, tista, ki omogoča svobodo misli in izražanja. Takšno razmišljanje je osnovano na Spenglerjevi dualnosti med civilizacijo in kulturo, ki jo leta 1918 avtor predstavi v delu Propad Zahoda. Civilizacijo razume kot upad kulture oziroma njen zadnji stadij.

Vidimo, da se stališča Zenita umeščajo v širši diskurz o krizi Evrope, ki je dosegla stadij stagnacije in degeneracije. Tema barbarogenija in balkanizacije Evrope ni značilna samo za zagrebški in beograjski Zenit, ampak tudi za slovensko avantgardo, posebej za Srečka Kosovela. ${ }^{2}$ Poleg znane sintagme »Evropa umira je za Kosovela značilno tudi sledeče stališče: "'Evropa norišnica civilizacije in hiperintelektualizma' s paralitično kulturo v stadiju 'progresivne paralize' " (Kosovel, Zbrano 3 ,31) medtem ko je bilo v slovenstvu 'premalo barbarstva [...] in krvi' (nav. d. 640)« (Vrečko 266). Janez Vrečko v svoji razpravi o Kosovelu dodaja, da je Kosovel »ostro razmejil barbare, zdrave, gole, močne, zagorele, od gospodov v fraku s sifilisom «, ter da barbarstva ni povezoval samo z Balkanom, ampak tudi s slovenstvom (267). Kosovel se sklicuje na Micićevega barbarogenija, ko govori o »barbarsko primitivnem umetniku-geniju« (Kosovel 3: 608) ali pa povezuje Balkan z »dinamizmom", "aktivnostjo« in ga okliče za »Temelje bodočnosti« (Kosovel 2: 43). Podobno lahko zasledimo tudi v reviji Tank (1927) v manifestih Ferda Delaka, kjer beremo, da mora Ljubljana "postati 'garage' svetovne drveče lepote. To je parola balkanske narave« (Delak, "Mladina« 5) ali pa »biti hočemo barbaro-geni« (Delak, "Mi« 69). V istem duhu piše tudi Avgust Černigoj Miciću ${ }^{3}$ v Pariz 3. marca 1927: „Verujem tudi

${ }^{2}$ Lado Kralj najde identifikacijo z barbarstvom v delih Srečka Kosovela, Ferda Delaka in Avgusta Černigoja, majhen fragment pa odkrije tudi pri Tonetu Seliškarju (Kralj 38).

${ }^{3}$ Černigoj se je z Micićem srečal v Trstu, ko je ta prek Reke in Trsta odšel v Pariz. Takrat mu je Černigoj predal nekaj konstruktivističnih del z namero promocije in 
trditev da smo mi Barbari mnogo bolj podkovani in umetniško nadarjeni kakor vsa francoska italijanska in germanska komercielna prostitucija. [...] Zaključujem z besedo Barbaro-kreacija mora biti higienično zdravilo umet (navedeno v Golubović, "Dopisovanje« 102). Podobno zasledimo tudi v reviji Dada-Jok Branka V. Poljanskega: "Ne sme se ceniti nihče iz Zahodne Evrope" (Poljanski, "Zakonik« 3).

Revija Zenit je bila od samega začetka programsko zavezana kozmopolitskosti, kar se tudi na splošno pripisuje umetnosti historične avantgarde z začetka 20. stoletja, ki je izzivala najrazličnejše kulturne kalupe in družbene identitete ter spodbujala vsakršno osvobajanje, še posebej osvobajanje od družbenih spon. Zenitistično gibanje, ki se je razvilo okrog revije, je nastalo kmalu po letu 1918 ob formuliranju nove balkanske države Kraljevine Srbov, Hrvatov in Slovencev:

Micićeva ideja o mobilizaciji duha mladih ustvarjalcev za mir in sodelovanje med narodi, državami, celinami in kulturami je postala osnova estetskega programa Zenita. Tako kot združitev Italijanov v 19. stoletju se je ideja o skupni državi - Kraljevini Srbov, Hrvatov in Slovencev uresničila po prvi svetovni vojni (kasneje se bo imenovala Jugoslavija) in Micić, njegov brat Poljanski ter vsi drugi sodelavci Zenita so to poveličevali (Subotić, "Zenitism« 216).

Ob tem značilno avantgardističnem diskurzu, osnovanem na kozmopolitskosti in internacionalnem, je treba omeniti tudi dejstvo, da se Micićev junak barbarogenij v določenem trenutku tudi zelo jasno lokalizira ter postane zavezan nacionalnemu in srbstvu, zaradi česar nekateri teoretiki označijo Micića tudi za srbskega nacionalista. Ravno zato je Micićeva pozicija pomembna za našo raziskavo, saj lahko njegova stališča hkrati tematiziramo $\mathrm{z}$ avantgardistične, internacionalistične vizure, ki se upira kapitalu ter se navdušuje nad boljševizmom na eni strani, in nacionalne oziroma nacionalistične vizure, ki se navdušuje nad srbstvom.

Prav skozi koncept barbarogenija je v širšem kontekstu evropske avantgarde možno določiti in kartirati izvirne teme, značilne za lokalni prostor jugoslovanske avantgarde. Tematizacija barbarstva in odnosa med Evropo in Balkanom vsekakor predstavlja eno od pomembnih nalog, ki jo je bilo treba dovršiti, da bi se jugoslovanska avantgarda integrirala $\mathrm{v}$ zgodovino evropske avantgarde kot izviren literarno-ume-

internacionalizacije slovenskega konstruktivizma v tujini. Prekinitev izhajanja Zenita pomeni tudi pričetek programskega formiranja slovenske avantgarde in izdajanja revije Tank, o čemer pričajo pisma Černigoja in Delaka Miciću. Ohranjena pisma so bila natisnjena v reprintu Tanka leta 1987 s spremnim besedilom Vide Golubović »Dopisovanje v zvezi z revijo Tank«. 
tniški tok. Ravno takšne izvirno (južno)slovanske teme pričajo o izvirni misli in umetnostno-zgodovinski specifiki jugoslovanske avantgardne struje. Gre za povezavo s specifično zgodovinsko situacijo Zahodne Evrope tistega časa, ki rezultira tudi v nameri avantgardističnih struj, ki se razlikuje od tistih na Zahodu. Po razpadu Otomanskega, Ruskega in Avstro-Ogrskega cesarstva se znotraj novonastalih držav v ospredje postavi ravno vprašanje lastne narodne identitete in kaj je tisto, kar te države razlikuje od preostale Evrope. Micićeva potreba po gradnji narodne zavesti in odmiku od evropske kulture po prvi svetovni vojni je tako pravzaprav tudi kolektivna stvar vzhodnoevropskih držav. Čeprav je zenitizem predstavljal sintezo gibanj, kot so futurizem, ekspresionizem in dadaizem, se za razliko od njih zasnuje ob nasprotovanju napredku vzhodnoevropske civilizacije. Preko junaka zenitizma - barbarogenija - se oblikuje posebna lokalna identiteta, ki vzpostavlja tudi nacionalni kontekst gibanja. Marijan Dović ob tematiziranju kozmopolitizma in internacionalizma zenitističnega kroga prepozna Micićevo »balkanizacijo Evrope« tudi kot (uspešno) strategijo za preboj v mednarodni krog avantgardističnih gibanj (Dović 46).

Koncept barbarogenija si bomo v razpravi ogledali s pomočjo imagološke raziskave oziroma raziskovanja podob Drugega ali Tujega v literaturi, ki sicer ni značilna za raziskovanje gibanj zgodovinske avantgarde. To je nenavadno na prvem mestu zato, ker je običajno ravno historična avantgarda tista, ki ukinja razmejitve bodisi med narodi in družbenimi razredi bodisi med različnimi umetnostmi. Umetnost historične avantgarde je največkrat pojmovana z označevalci kozmopolitskega odnosa do Drugega, še posebej v prvih gibanjih, kot je zgodnja ruska avantgarda oziroma ruski kubofuturizem, izrazit primer pa je tudi začetek dadaistične struje v Zürichu. Avantgardna gibanja so temeljila na principu nekonformizma, antitradicionalizma in nove kulturne produkcije, ki bo zunaj institucionalizirane kulture. Te ideje zgodovinskih avantgard so izvirale iz vizije, da je možno po grozotah prve svetovne vojne združiti ljudi v antimilitarističo gibanje, ki bo rodilo novega človeka. $\mathrm{Na}$ geografskem področju Balkana so bile spremembe izrazite - južnoslovanski narodi so se znašli v skupni državi, čeprav do takrat niso imeli skupnega zgodovinskega razvoja. To združevanje je podprla tudi revija Zenit, ki je bila izvorno namenjena mednarodni umetnosti, o čemer priča njen podnaslov "Internacionalna revija za umetnost i kulturo". Avtorji so objavljali v svojih maternih jezikih, marsikdo pa je objavil tudi dela, ki jih je napisal v tujem jeziku. Zenit je tako predstavljal nekakšno spojno točko kakofonije različnih jezikov, kultur in izrazov. Drugost oziroma Tujost je na ta način vključena $v$ 
množico glasov, ki ohranjajo svojo individualnost v skupnem (v reviji in zenitističnem gibanju). Hibridizacija kultur in različnih tradicij je vidna tudi v naslovu revije, ki je bil zapisan hkrati z latiničnimi in ciriličnimi črkami: 3enit.

\section{Razvoj dualnosti »Evropa-Balkan"pri Ljubomirju Miciću}

$\mathrm{V}$ prvi deklaraciji zenitizma "Človek in umetnost" iz prve številke Zenita (1921) beremo, da je "človek" "center makrokozmosa" in da želijo zenitisti odkriti novo svetlobo, ki bo "svetila v mraku Jugoslavije» (Micić, "Čovek« 1). V novo, tretje desetletje 20. stoletja si želijo zenitisti "prek mej Jugoslavije» (prav tam). Njihova namera je, da postanejo internacionalno gibanje. Značilno je izrazito pacifistično stališče in obsojanje grozot prve svetovne vojne, katerih glavni krivec je »civilizirana Evropa«. Zato zenitisti kličejo k novi, "vsečloveški kulturi« ter "vsesplošni - vsečloveški umetnosti«: »In zato ni specifično nacionalne umetnosti, še manj pa razredne umetnosti« (prav tam). Ekspresionistični klic po novem človeku je povezan z ustvarjanjem novih vrednot, »borbo za svobodo in afirmacijo individualizma", "proti vsaki tradiciji, proti vsem regionalizmom in mejam«, ker "za umetnost in človeka - ni mej!« (Micić, "Čovek« 2). Zenit se tako vzpostavi kot prostor brez meja, ki je namenjen boju za internacionalno kulturo in nadnacionalnega človeka, zenitizem pa kot "vera" zenitistov in "abstraktni metakozmični ekspresionizem«. Edino oprijemljivo vodilo, ki ga izpostavijo avtorji zenitisti, je anarhizem oziroma "polbog Anarh«, ki je »najvišja manifestacija duha in duše», umetnost pa je za njih »večna dinamika, gibanje, večna anarhija, večna revolucija» (prav tam).

V manifestu »Duh Zenitizma«v Zenitu št. 7 (1921) Micić že jasno formulira jugoslovansko-balkansko specifiko, ko pravi, da se je v »jugoslovansko-balkanski zibki« rodil nov duh, ki je »integralen, neodvisen duh ustvarjalnega individualizma", ki je edini sposoben ustvarjati nove oblike (Micić, »Duh«4). Ker Jugoslavija nima svoje kulturne tradicije razen "Kraljeviča Marka in Kosova" (prav tam), je Zenit tisti, ki jo bo ustvaril na novo - nova umetnost zenitizma se torej postavlja nasproti nacionalistični tradiciji. Ne gre za avantgardistično destrukcijo tradicije, torej da bi se začelo ustvarjati iz nič, ampak za zgodovinske okoliščine, ki so ustvarile realno možnost za začetek nove, skupne in pluralne kulture več narodov. V tej deklaraciji je prisotna tudi ideja zenitista-barbara: "Poslednji barbari so samo predhodniki prvih zenitistov« (prav tam). In nadalje: 
"Mi smo goli in čisti« (Manifest zenitizma) pomeni: v čisti zibelki, v jugoslovansko-balkanski zibelki se je rodil nov duh - integralen, neodvisen - duh ustvarjalnega individualizma. [...] Rodil se je nov duh ene močne rase, ki do sedaj še ni imela svoje umetnosti in kulture. [...] Človeštvo se stoletja mučno rojeva, ampak Zahod ni bil dovolj močan, da bi ga rodil, ker ne pozna religije občutkov, ampak samo religijo misli. (Tu leži zlom zahodne kulture in njenega lažnega humanizma!) Religija občutkov in misli se rojeva na JUGOVZHODU [...] Balkanski človek - prvi zenitist. ZENITIZEM: ETIKA ČLOVEKA. Junaštvo Duha: Barbaro-Genij. Barbaro-Genij: največja moč duha - pojem Maksimalnega duha (Micić, »Duh«4-5).

$\mathrm{Na}$ začetku naslednjega manifesta, naslovljenega "Delo zenitizma", iz osme številke revije Zenit (1921) se Micić očitno sklicuje na Nietzschejevega nadčloveka, ki je tudi sicer osrednja referenca njegovih manifestnih besedil: »[D]anašnji evropski človek: plesalec je na goreči vrvi, ki je nategnjena med Kremljem in Eifflovim stolpom« (Micić, »Delo« 2). Tukaj Micić že zelo jasno napove »dvoboj kultur« in vzpostavi protievropsko paradigmo in idejo, da mora žarišče nove kulture postati Vzhod. "Vsečloveška slovanska koncepcija Vzhoda» je torej tista, ki bo prerodila Evropo:

Ta hibridnost zenitizma je bila nadnacionalna, transdisciplinarna, transracionalna, blizu ruskemu avantgardističnemu zaumu, pa tudi blizu orientalskim fantomom iz mističnega vzhoda, ki se borijo proti racionalnemu Zahodu, sledeč idejam in spominu na Dostojevskega, Berdjajeva, Majakovskega, Aleksandra Bloka, Nietzscheja in Dimitrija Mitrinovića (1887-1953). Slednji je bil ezoterični srbski filozof in pesnik, rojen v Hercegovini (pod AvstroOgrsko), s svojo karizmo guruja, ki jo je zgradil v Angliji na začetku dvajsetih let 20. stoletja, je bil sedaj ponovno odkrit (Subotić, "Zenit, Zenitism«).

Namesto D'Annunziovega »Fuori i barbari!« Micić vzklikne »Napolje Latini!" Prihaja človek heroizma, „VZHODNJAK», »človek z Urala, Kavkaza in Balkana - rojen v zibki, ki se imenuje Rusija " (Micić, »Delo" 2). Zenitisti bodo tisti, ki bodo utrdili most za borbo proti zahodni civilizaciji in Evropi: "Balkan je MOST med Vzhodom in Zahodom» (prav tam). Vidna je ideja panslavizma in obračanje $\mathrm{k}$ Rusiji kot protipolu zahodne kulture.

Zahvaljujoč tej sinkretični formuli in zlasti novim idejam o metaforični, močni, zdravi figuri Barbarogenija, ki prihaja z balkanskih višin in ki naj bi »balkaniziral" staro in utrujeno Evropo, so bile te izjave izvirne, zelo provokativne in zato splošno sprejete s strani mladih avantgardnih krogov. Te ideje so odražale neoprimitivne težnje, ki izvirajo iz Rusije in so bile blizu tako primarni nadrealistični fazi kot tudi splošnemu interesu za zgodnje kulture, kot sta afriška 
in črnogorska umetnost, ki je bil prisoten v Evropi v tistem času. Blizu so bile tudi skitstvu, pri katerem je pesniški jezik obogaten s prvinskimi izrazi, čistimi, golimi, neposrednimi, izvirnimi opisi, neodvisnimi od pomena, podobnimi Parole in Libertà ali besedam v prostoru (Subotić, "Zenit, Zenitism«).

Ob tem ne moremo mimo pesmi "Skiti« ${ }^{4}$ Aleksandra Bloka iz leta 1918, ki jo je Micić objavil že v tretji številki revije Zenit na prvi strani. $\mathrm{V}$ tej pesmi Blok predstavi novega barbara, ki je Skit oziroma Slovan in prinaša novo kulturo z Vzhoda:

»Mi kot poslušni sužnji, «je zapisal Blok, »držimo ščit med dvema sovražnikoma ras - Tatari in Evropo!« (2. kitica). Ta del vzbuja občutek, ki je bil zelo blizu zenitistični nameri: soočanje z zgodovinskim statusom Balkana kot cordon sanitaire, ki varuje Habsburžane pred osmanskimi vpadi, in poskus spodkopati to stališče s sprejemanjem Vzhodne drugačnosti (ki je sovražna Zahodni) kot sile emancipacije. Očaranost nad pesmijo Bloka o identifikaciji z vzhodnjaškim Drugim je jasna: "Da, mi smo Skiti!« piše: »Da, mi smo Azijci, / s poševnimi in pohlepnimi očmi!« (1. kitica). Blokovo opozorilo Evropi - »mi nismo več tvoj ščit! - je še posebej pomembno (Glišić in Vujošević 723-724).

Podobno antievropsko tendenco in poveličevanje balkanskega človeka najdemo tudi v Micićevi poeziji. Nadvse povedna je predvsem njegova "antievropska poema" Aeroplan brez motorja (1925), v kateri je tipografsko poudarjen napis "Evropa ali smrt napihnjene žabe« in vprašanje "Ali je še mesto za balkanskega človeka?». Knjiga je bila leta 1925 uradno prepovedana, ker naj bi žalila javno moralo. Tožbe zaradi svojega prevratnega dela je Micić objavljal v Zenitu, ob njih pa je tiskal tudi svoje zapise, v katerih se je branil, da je njegova knjiga »visoko etična in humana", ter svoje delo povezoval s svobodo in čistostjo »balkanskega človeka«:

Moja poema je boleč krik svobodnega in čistega BALKANSKEGAČLOVEKA, ki je globoko in iskreno ogorčen nad vso nemoralnostjo in izmečki, ki nas davijo pod imenom Evropa in evropska kultura. [...] Ta mora [Evropa] je zajahala moj prekrasni Balkan, za katerega kulturno emancipacijo sem prvi dvignil svoj pesniški in človeški protest s svojim hudournikom močnih besed v našem burnem, še nevstalem jeziku. [...] Ali je RESNICA lahko nemoralna? Ne! Nobena resnica ni nemoralna. [...] Resnica ne more biti nemoralna tako

${ }^{4}$ Skiti (rus. Skifi) je grški naziv za geografsko področje starodavne Hileje, pokrajine skitskega ljudstva, ki se nahaja severno od Črnega morja (ta del je včasih pripadal Rusiji, danes je del Ukrajine). Iransko nomadsko pleme Skitov je bilo navdih za simboliste in naslov njihovega zbornika Skiti, po Hileji (rus. Gileja) pa je ime prevzela ruska kubofuturistična skupina. 
kot umetnost. Resnica je onkraj morale in nemorale (Micić, »Iz dosijea« 432, 434, 438).

Kot zadnji primer bomo izpostavili prozno delo Barbarogenij Decivilizator, ki ga je Micić napisal v izgnanstvu v Parizu, kamor je odšel leta 1927 po prepovedi izdajanja Zenita. ${ }^{5}$ Gre za roman o zenitističnih idejah, ki se realizirajo v junaku z imenom Barbarogenij. Roman je prepleten $\mathrm{z}$ avtobiografskimi referencami pisatelja: $\mathrm{v}$ uvodu, ki sestavlja okvir romana, izvemo, da želi avtor, neznani srbski pisatelj, na svojem študijskem potovanju po Balkanu najti literarno delo za francoske bralce, v katerem bi bil prikazan slovanski duh Srbije. Takšen roman, ki ga predstavlja osrednji del Barbarogenija, najde v arhivih Dubrovnika med starimi rokopisi (Micić, Barbarogenij 10).

Barbarogenija spremljamo od njegovega rojstva - na presenečanje vseh se rodi kot odrasel človek in kmalu po rojstvu z vzklikom »Eureka!« iznajde zenitizem (26). Kamor koli gre, razglaša svojo zenitistično vizijo in stališče, ki je proti mehaničnemu človeku, ki ničesar ne čuti, ampak samo misli o napredku. Roman je osnovan na temah sprevračanja oblasti stroja oziroma mehanizacije in oblasti denarja. Zato je akt uničevanja stroja predstavljen kot boj proti kapitalu (141). Pod kritiko avtorja se znajde tudi trgovanje, ki je postalo gibalo sveta, namesto da bi to gonilo predstavljal zenitizem (18). Kapital, mehanizacija, trgovina so označevalci, ki so za avtorja izraz zahodnega sveta, Evrope, kjer je vse "fasada" ali polakirana zunanjost, pod katero ni ničesar (130).

$\mathrm{V}$ romanu se pojavi tudi polemika $\mathrm{z}$ osrednjo figuro italijanskega futurizma T. F. Marinettijem, ki je zavzemal stališče, da je zenitizem pravzaprav zgolj srbski futurizem, medtem ko so ju zenitisti strogo ločevali. Barbarogenij Marinettiju zastavi sledeče vprašanje: "In od kje ti še vedno pogum za povezovanje splošnočloveškega in barbarskega zenitizma z nečloveškim in splošnomehaničnim futurizmom!? (95). Odnos Micića in zenitistov do italijanskega futurizma je v našem prevpraševanju avantgardno-nacionalističnega konteksta jugoslovanske avantgarde pomemben, ker gre za sočasno evropsko avantgardno strujo, ki je imela izrazito nacionalističen značaj. Čeprav je bil Marinetti Micićev znanec in ga je enkrat celo rešil iz italijanskega zapora, ${ }^{6}$ Micić ni nikoli sprejel

${ }^{5}$ Čeprav je v tem času zenitistično gibanje znotraj jugoslovanske avantgarde že izgubilo svojo moč in je pravzaprav zamrlo s prepovedjo izdajanja revije leta 1926, je duh zenitizma trajal vse do Micićeve smrti.

${ }^{6}$ Peter Krečič najde temeljni izvor izraza »barbaro-genij« Micića in slovenskih avantgardistov pri Marinettiju, ki je zapisal stavek: „Ebbene, si siamo barbari!«, o barbarih-futuristih pa je leta 1920 pisal tudi v manifestu "Contro il lusso femminile» 
kolaboracije italijanskih futuristov s fašisti in je takšne oblike umetnosti (podobno kot zgodnji ruski avantgardisti - kubofuturisti) obsojal:

Latentne razlike med futurizmom in zenitizmom, zlasti na političnem področju, so se pojavile v neposrednem dialogu med Marinettijem in Poljanskim v pariškem hotelu Grand, po predavanju Marinettija o fašizmu in futurizmu 28. oktobra 1925 na Tribune libre des femmes $\mathrm{v}$ času Mednarodne razstave za dekorativno in industrijsko umetnost. Branko Ve Poljanski je bil - tako kot njegov brat Micić - veliko bližje boljševiški ideologiji in levičarskemu futurizmu. Njuna kontroverzna razprava je bila v italijanskih in jugoslovanskih medijih tistega časa različno interpretirana. Poljanski je govoril v srbščini in nemščini in je bil očitno proti futuristično-fašistični navezi. Marinetti, ki sta ga spremljala Fortunato Depero in Enrico Prampolini, je govoril v italijanščini in francoščini. Italijanska revija $L$ 'Impero je pisala, da sta govorila o futurizmu in zenitizmu, fašizmu in pasatizmu. Isti dogodek je bil v reviji Zenit predstavljen precej drugače, v poročilu, ki ga je napisal Poljanski osebno: kot piše v Zenitu, je Marinetti pojasnil, da je bil futurizem predhodnik in prekurzor fašizma, Poljanski pa je nasprotoval ideji o njunih povezavah. Pritožil se je nad diskriminacijo Hrvatov in zaprtjem jugoslovanskih šol v Istri, pa tudi nad požigom Slovenskega doma v Trstu s strani fašističnih sil (Subotić, "Zenitism« 223-224).

V nasprotju z italijanskim futurizmom, ki je bil tesno vpet v takratna družbenopolitična gibanja, je Micić koncipiral zenitizem kot popolno revolucijo duha. V romanu Barbarogenij decivilizator zato Barbarogenij jasno zavrne tudi vsako družbeno revolucijo:

Kako decivilizirati svet, ki od nastanka Evrope ne počne nič drugega, kot da sam sebe denaturalizira, se je nekaj mesecev pozneje $\mathrm{v}$ Parizu vprašal Barbarogenij. O, moj bog! Da bi se svet vrnil v svoje naravno stanje, humane razmere ali na raven kultiviranih bitij ni dovolj ena revolucija, temveč več revolucij. Kar pa se mene tiče, se zgrozim nad tako imenovanimi družbenimi revolucijami, ki so narejene zgolj za krožnik juhe več ali za dva namesto enega kosa kruha (Micić, Barbarogenij 114).

(Krečič 69). Lado Kralj pa tolmači poetiko jugoslovanskih in ruskih avantgardistov v skladu z Marinettijevimi »negativističnimi gesli«, kot so totalitarnost, nihilizem, ekstremizem, k čemur prišteva tudi "barbarstvo«, ki ga povezuje z radikalnim patriotizmom, šovinizmom in rasizmom (Kralj 30). Pri tem gre za enodimenzionalno enačenje, ki odreka razliko predvsem ruskega futurističnega gibanja, ki je bilo zaznamovano $\mathrm{z}$ izrazito pacifistično in kozmistično miselnostjo ter elementi primitivizma in arhaike. Teoretičarka Nina Gurjanova v knjigi The Aesthetics of Anarchy: Art and Ideology in the Early Russian Avant-Garde (University of California Press, 2012) prepričljivo pokaže, da sta za italijanski futurizem značilni mehaničnost in unifikacija stilov znotraj gibanja, česar ne najdemo niti v zgodnji ruski avantgardi niti v jugoslovanskih avantgardističnih gibanjih. 
Barbarstvo oziroma »barbarska epoha ljudske kulture« ni »vrnitev k divjaštvu, pa tudi ne vračanje na začetek«. Nova doba ni ne divja ne civilizirana. Ne gre po horizontali, ampak samo po vertikali, ki je "zenitistična pot« (144). Ta pot pa je v tem Micićevem delu v francoskem izgnanstvu, kjer je doživel podobno razočaranje in nesprejetost kot $\mathrm{v}$ Zagrebu in Beogradu, zelo očitno ukoreninjena v srbstvo in srbsko kulturo. Micić v tem romanu poleg Evrope in kapitalizma kritizira tudi jugoslovanstvo in še posebej Hrvate, ki jim očita, da imitirajo Evropo. ${ }^{7}$ V Barbarogeniju piše o jugoslovanski brezizraznosti:

Čeprav sem bil politično na jugoslovanskih tleh - in nacionalno na srbskih! po vsem, kar sem videl na ladji "Dubrovnik«, sem imel občutek, da plujem na ladji, ki ni imela niti lastne nacionalne fizionomije. Rekel bom celo, da gre tukaj za državo brez profila, brezosebno in brezizrazno. In vse to mi je ustvarilo naslednjo sliko: sliko razbitih jajc, s katerimi se še nikomur ne sanja, kako narediti umešana jajca - srbska umešana jajca, seveda (9).

Micić govori tudi o večvrednosti zgodovine srbskega naroda in upravičenosti Srbije do lastne, samostojne države in nacionalnosti:

In potem, degenerirati veliki srbski narod, ga zvesti na pleme, na vejo neobstoječe narodnosti - srbski narod ni veja, ampak pravo drevo, ena celota - izenačiti srbski narod z več slovanskimi plemeni, brez preteklosti in zgodovine, katoliškimi ali muslimanskimi v nekdanji Avstro-Ogrski, predstavlja več od največje napake, predstavlja neoprostljivo žalitev (89).

Tik pred začetkom druge svetovne vojne se je Micić z ženo Anuško vrnil iz Pariza v Beograd. Pariz, takratna evropska metropola, mu je bila podobno kot domače okolje nenaklonjena. Tudi tu ni našel razumevanja za svoje delo in nazore. V Beogradu je nato leta 1940 objavil literarno-politični časopis Srbijanstvo, v katerem je objavil tudi "Manifest srbijanstva«. Časopis - eno izmed poslednjih tiskanih Micićevih del je bil prepovedan in ni doživel nikakršnega uspeha ali odziva.

\section{Balkanski divjak kot imaginarni konstrukt Evrope}

Micić je bil kritik inferiornega položaja Kraljevine SHS, ki ga je ta zavzela do Evrope, čemur se je najprej uprl s povzdigovanjem nadnacionalne balkanske, nato pa nacionalne, srbske kulture. Natančneje,

${ }^{7}$ Podobna misel o hrvaški kulturi je izražena tudi v Micićevem članku »Papagaj in monopol 'hrvaška kultura' «, objavljenem leta 1923 v 24. številki revije Zenit. 
avtor je kritiziral pravzaprav vse, kar je bilo v kulturi inferiornega in podjarmljenega ter se je zaradi svojega manjšega dosega in nižje vrednosti moralo zgledovati po večvrednem gospodarju - Evropi. Poleg internacionalizacije je pri Miciću torej vidna tudi strategija vzpostavljanja balkanskega, pozneje pa tudi srbskega kulturnega sveta kot večvrednega od evropskega. Vse to so strategije za osvobajanje Balkana od Evrope in za njegovo vzpostavitev kot celovite kulturne entitete $\mathrm{z}$ lastno ustvarjalno močjo.

Podobo balkanskega človeka kot barbara, človeka nebrzdanih močnih čustev, ki se zoperstavlja redu in civilizaciji, lahko zasledimo tudi danes. Marina Abramović na koncu predavanja ob svoji retrospektivi v Muzeju sodobne umetnosti v Beogradu pove sledeče: "Jaz sem z Balkana, in če živiš nekje daleč v svetu, imaš Balkan vedno v sebi. Balkan je na mostu med Vzhodom in Zahodom, na vsakem mostu pa pihajo zelo močni vetrovi. Mi smo produkt teh vetrov in vetrov, samih s seboj. Zato imamo energijo, da lahko noro ljubimo in sovražimo, da smo občutljivi, da pozabimo ... To so elementi mojega dela" (zapis po predavanju Marine Abramović, 28. 9. 2020, Muzej sodobne umetnosti v Beogradu).

Barbarogenij kot podoba balkanskega človeka, ki je na prepihu med Vzhodom in Zahodom, ima tako še vedno posebno mesto v socialnem imaginarju, ki določa kulturo in družbeno ureditev. Vsa besedila (tudi avantgardistična) so deloma programirana in vsak, ki pozna določeno kulturo in njen besednjak, lahko podobo dekodira oziroma neposredno interpretira. Cilj je torej ponazoriti in razložiti, na kakšen način funkcionira podoba kot simbolični jezik znotraj nekega literarnega sistema in socialnega imaginarija (Pageaux 11-12).

Dubravka Ugrešič Balkan izenači z ogledalom, v katerem se Evropa ves čas ogleduje in na ta način gradi svoj narcizem. Podobno trdi tudi Marija Todorova: "Tako kot Zahod je bil tudi Balkan primeren in še vedno je za odlaganje negativnih karakteristik, nasproti katerih smo postavili pozitiven in samozadovoljen odraz v ogledalu 'evropskega' in 'Zahoda'" (Todorova 287). Na zenitistične strategije balkanizacije in barbarizacije Evrope lahko v tem kontekstu gledamo kot na poskus, da se ta prostor iztrga poziciji "žrtve« Evrope, ki po Todorovi predstavlja središčni patos balkanskega diskurza in je bil ustvarjen skozi več stoletij.

V literaturi lahko oznako »barbar« za poimenovanje južnih Slovanov ali Slovanov nasploh prvič zasledimo na prelomu 18. in 19. stoletja v francoskih literarnih in publicističnih delih, ki oblikujejo mit o dobrem divjaku, barbaru ali primitivcu v potopisih in časopisnih člankih, iz katerih so gradivo za svoja dela kasneje črpali avtorji, kot so Charles 
Nodier, Victor Hugo, Balzac, Nerval in George Sand (Sekeruš 195, 200). Gre za čas, ko Evropa odkriva vlogo in pomen neruskih slovanskih narodov - ta interes je bil torej politične narave, povezan $\mathrm{z}$ ohranjanjem evropskega strateškega ravnovesja (194). ${ }^{8} \mathrm{~V}$ kontekstu romantičnih načel je bilo prvotno navduševanje nad eksotičnim, divjim, primitivnim življenjem, ki se ga civilizacija še ni dotaknila, pozitivno predznačeno, hkrati pa so ravno te podobe kasneje postale argument, "na podlagi katerega se je v skladu z razvojnimi teorijami taisto civilizacijo opredeljevalo kot zaostalo« (203). Prvotno idealizacijo »dobrega divjaka" na začetku 19. stoletja zamenjata "barbar" in razvrednotenje romantičnega junaka, ki postane posledično manjvreden Drugi: „Njegova drugačnost odbija. Idealizacija dobrega divjaka se spreminja v občutek večvrednosti nad divjakom. Divjaki so najnižje na hierarhični lestvici bitij. Manjkata jim gospodar in civilizacija» (202).

Konstruiranje Balkana kot neciviliziranega in nasilnega Drugega $v$ odnosu do Evrope se je v družbeno-političnem kontekstu po prvi svetovni vojni samo še okrepilo, ko je pojem »balkanizacija» postal tudi geopolitični termin, ki označuje »razpad velikih in uspešnih političnih enot", hkrati pa je pomenil tudi "sinonim za vrnitev na plemensko, zaostalo, primitivno, barbarsko« (Todorova 3). Ta oznaka je bila utemeljena na preprostem dejstvu, da je bil Balkan manj razvit od Evrope:

Ker geografski vzhod Evrope in svet, ki se nahaja vzhodno od Evrope, zaostajata za Evropo predvsem v gospodarski uspešnosti, je Vzhod postajal bolj pogosto in velikokrat tudi izključno identificiran z industrijsko zaostalostjo, pomanjkanjem naprednih družbenih odnosov in institucij, ki so značilne za razvit kapitalistični Zahod, iracionalnimi in vraževernimi kulturami, ki niso bile v stiku z zahodnim razsvetljenstvom. To je dodalo dodaten vektor v odnosu med Vzhodom in Zahodom: čas, ko gibanje od preteklosti do prihodnosti ni bilo zgolj gibanje, ampak evolucija od preprostega do zapletenega, nazadnjaškega do razvitega, primitivnega do kultiviranega (Todorova 11-12).

Besede oziroma leksikalne mreže so tiste, ki v določeni kulturi in določenem času ustvarijo nek socialni imaginarij ali podobo o drugem - ta pa nato ustvari hierarhizirano razmerje oziroma sistem oseb in določen scenarij oziroma zgodbo (Pageaux 14-18), ki deluje in vpliva na konstruiranje identitet in družb. Ob tem se velja spomniti na temeljno performativnost identitet, ki niso nikoli nekaj fiksnega, ampak so ustvar-

${ }^{8}$ Glej tudi Roger-Pol Droit Généalogie des barbares (Odile Jacob, 2007) in Tzvetan Todorov On Human Diversity: Nationalism, Racism and Exoticism in French Thought (Harvard University Press, 1993). 
jene s pomočjo ponavljajočih se "govornih dejanj« (po jezikoslovcu J. L. Austinu in kasneje filozofinji Judith Butler). Teorija performativnosti je že bila aplicirana na delo Ljubomira Micića, revijo Zenit in koncept barbarogenija (Glišić in Vujošević 732), in sicer v kontekstu premišljevanja možnih strategij, s katerimi bi bilo možno ustvariti nove označevalce za Balkan kot pozitivne, kreativne sile v normativnem diskurzu:

Najpomembneje je bilo, da so [zenitisti] želeli preoblikovati evropske klišeje o balkanski zaostalosti in agresivnosti, tako da so se poistovetili z »Balkanom» in ga predstavili kot tisto, kar so poimenovali s pojmom »Barbarogenij«. Ta novi tip človeka je bilo treba obravnavati kot figuro, katere svež, primitiven in ustvarjalni genij bo osvojil in pomladil utrujeno evropsko kulturo. [...] Hkrati pa je gibanje predstavljalo tudi svojevrsten in radikalen poskus, da bi se omajal pomen in položaj, ki ga je Balkan dodeljeval hegemonskemu zahodnoevropskemu diskurzu (Glišić in Vujošević 719).

Barbarogenij pri Miciću postane skupek vseh klišejev balkanske zaostalosti in agresivnosti. »Barbarogenij = Balkan « predstavlja figuro, ki bo vnesla ustvarjalnega genija in svežino, $s$ katero bo pomladila utrujeno evropsko kulturo. Ob tem pa gre tudi za poskus, da bi se premagal hegemonski zahodnoevropski diskurz. Opazimo, da v teh delih ne gre za izražanje podobe Evrope, ki naj bi bila zasidrana v imaginariju kulture Balkana. Bistvo tega zenitističnega oziroma Micićevega poskusa je ravno v opozarjanju na žrtev, ki jo igra Balkan, in v kazanju njegove lastne podobe. $V$ tem pogledu gre za avtostereotipizacijo, ki jo je Micić vršil izredno radikalno, da bi spodkopal manjvrednost in podredljivost Vzhoda oziroma Balkana. Micić ne ustvarja novega imaginarija, ampak uničuje obstoječega - uničuje tisto, čemur bi lahko rekli fobija Zahoda do Balkana, kjer je »tuja realnost pojmovana kot manjvredna $v$ razmerju do izvorne kulture« (Pageaux 19). Avtor zelo jasno izreče, da je Evropa tista, ki ima problem, in ne Balkan.

Vendar pa lahko celo v spremni besedi romana Barbarogenij Decivilizator preberemo, da je to delo "projekcija primitivne balkanske kulture v evropski prostor « (Golubović, »Pogovor« 162), čemur lahko na tem mestu oporekamo. Pri Miciću je namreč Evropa tovrstno kulturo že dolgo sama projicirala na Balkan, avtor pa v svojih delih to sprevrača z namenom, da bi ustvaril novo vrsto kulture oziroma povzdignil Balkan na raven, ki si jo je prisvojila Evropa.

Podoba v literaturi se uporablja kot izraz za metaforične izraze, opise, ki kažejo na odnos do nekega predmeta ali osebe - so rezultat spominjanja in proizvod kulture, so torej "subjektivne, avtobiografske" (Sekeruš 194). Gre za metafore, v katere verjamemo, kot da so resničen 
odsev sveta:' " Takšna predstava ni le nekaj, kar preprosto obstaja, marveč je idejni konstrukt, ki je s stvarnostjo v zapletenem odnosu - le-ta postavlja pod vprašaj možnost resničnega razlikovanja med Jazom in Drugim ter celoten svet omeji na podaljšek in odsev tega Jaza« (prav tam). Podoba torej nastane tam, kjer se dve kulturni realnosti ključno razhajata, vendar pri tem nikakor ne gre za ukvarjanje z lažnostjo podob; "vsaka podoba je lažna, saj je predstava in ubeseditev določene realnosti« (11).

Junak Barbarogenij v romanu izrazi misel, da je pri tujih piscih prisotna iznakažena ali prirejena slika srbskega naroda. Barbarogenij Hipokritu, očetu svoje izbranke Srbice, reče:

Navdihovati se in brati tuje pisce, da bi pri njih našli, da so Srbi prostaki in klavci ovc, razbojniki in morilci ... to pa ne! ... Ne mislite, da sem enak kot vaši rojaki, ki svet Srbov gledajo skozi slabe knjige in tujo propagando. Ker vi temu pravite nacionalna in evropska vzgoja. [...] In zagotavljam vam, da so v večini knjig samo hipokritski pogovori, če mi oprostite, gospodar Hipokrit. Zato rad prerokujem, ne razbiram iz knjig, ampak iz življenja, ljudi, sebe (Micić, Barbarogenij 27-28).

\section{Karnevalizacija ali nacionalni kompleks?}

$\mathrm{V}$ našem razjasnjevanju, od kod prihajajo in kako se formirajo sile balkanskega človeka $\mathrm{v}$ jugoslovanski avantgardi, ki jih je Micić postavil $\mathrm{v}$ središče zenitizma, nam je ostala še ena negotovost, povezana $\mathrm{z}$ Micićevim eklekticizmom. Zanimivo je, da sta Micić in njegov brat Branko V. Poljanski po prepovedi Zenita v Beogradu in izgnanstvu Micića v Pariz v ljubljanski reviji Tank (1927) objavljala svoja dela v francoščini. Kar ponovno zastavlja vprašanje, kako zakoreninjena je bila v Miciću srbska kultura oziroma manifestacija te kulture v nacionalističnem smislu.

$\mathrm{V}$ delih Micića lahko najdemo provokacije in parodijo tako lastnega, srbskega naroda kot tudi Hrvatov, monarhije, marksizma in fašizma. Avtor izenači vse družbene in kulturne konstrukte. Njegova reinterpretacija stvarnosti je polifona in vseobsežna, kar izpostavi tudi Irina Subotić, ko zapiše, da je zenitizem »zaznamovan s (postmodernističnim!) pluralizmom ali (bahtinovskim) večglasjem« (Subotić,

${ }^{9}$ V zvezi s tem omenimo ključno knjigo Metaphors We Live By (1980) avtorjev Georgea Lakoffa in Marka Johnsona, ki preučujeta, na kakšen način metafora oblikuje naš jezik, mišljenje in delovanje, ne da bi se tega sploh zavedali. 
"Odblesci«). Ob omembi polifonije lahko nadaljujemo, da pri Miciću govorimo tudi o Bahtinovi karnevalizaciji kot posebnem principu življenja, ki je posledica univerzalnega rušenja norm, preobračanja hierarhije in kršenja prepovedi. S tem je povezano tudi Micićevo iskanje korenin in zanimanje za srbsko zgodovino, kar dokazuje tudi avtorjeva zapuščina, $\mathrm{v}$ kateri izredno veliko knjig tematizira srbsko narodno zgodovino in identiteto (Subotić, »Pregled« 240-244). Manifestacije nacionalizma se lahko razumejo tudi kot plod kompleksa nižje vrednosti, ki je reakcija na dolgoletno potlačenost. Vračanje $\mathrm{k}$ tradiciji in nacionalni identiteti tako postane eden od načinov upora:

Zenitistični preobrat od »manjvrednega» do "večvrednega«, "nekultiviranega» do "civilizacijskega«, "perifernega» do »osrednjega» se zdi kot antikolonialna taktika, ki predstavlja možnost za izgradnjo novega sveta. Na ta način se je celo avantgardna in antitradicionalna retorika, ki se je začela kot »kozmična«, prisiljena vrniti k mitom o skupnosti, v kateri se ohranjajo tradicionalni vzorci samoohranitve kolektivne identitete (Pauly, »Nation«).

Ne gre za to, da bi avtor uničil arhetipe ali preprečil njihovo konstruiranje, temveč mit oziroma imagološko podobo poveča do skrajnosti in jo $\mathrm{v}$ romanu celo realizira v Barbarogeniju, kar deluje razdiralno in posmehovalno, ironično. Avtorjeva strategija postane vse, kar ni v skladu $s$ hegemonsko idejo resnice, objektivnosti, učinkovitosti in racionalnosti. Zelo zgovorna je definicija resnice, ki jo zagovarja Barbarogenij v romanu: »Resnica je zametek nenehnega upora proti provokacijam uniformne misli, proti strojnemu delovanju, ki mu pravimo civilizacija" (Micić, Barbarogenij 123).

Tudi teoretik Miško Šuvaković govori o Micićevih nomadskih ali anarhističnih strategijah, ki omogočajo nenehno spreminjanje pogleda, oblik izražanja, vrednot in ideologij: "Za Micićev zenitizem so bile značilne nasprotujoče si, eklektične in šokantne ideološke karakteristike in ga lahko $\mathrm{v}$ širšem smislu opredelimo kot anarhističen pristop z uporabo različnih strategij za provokacijo znotraj večjih ideologij panslavizma, nacionalizma, Nietzschejevega Übermenscha, boljševiške revolucionarne retorike, trockizma« (Šuvaković 25). Podobno tudi Irina Subotić meni, da je Micić zagovornik anarhoindividualizma (Subotić, "Odblesci«).

Metaforična figura barbarogenija, ki predstavlja balkanizacijo Evrope, je kontrastna slika mainstream procesa evropeizacije Balkana, ki poteka še danes. Politolog Žiga Vodovnik v svojem članku »Balkanizovati Evropu" omenja zenitizem kot primer iskanja evropske prihodnosti na ozemlju Balkana. Namesto »evropske poti« Vodovnik predlaga 
ravno nasprotno - paradoksno pot, ki gre prek Micićeve »balkanizacije Evrope« (Vodovnik, »Balkanizovati« 66). Balkan in barbarstvo sta v tem primeru oznaki za pluralizem in nadnacionalno, predstavljata literarni strategiji, ki omogočata kulturno in individualno emancipacijo. Kulturnozgodovinski procesi vplivajo na politično imaginacijo, hkrati pa literarna imaginacija vpliva na obliko teh procesov, saj jih formira v besede in podobe. Čeprav pri avantgardističnih tekstih ne moremo govoriti o tem, da ti utrjujejo ali potrjujejo zavest o neki določeni identiteti, lahko sklenemo, da pravzaprav prispevajo $\mathrm{k}$ transgresiji identitet. Osnovanje nove države po prvi svetovni vojni in avantgardistična dogajanja $\mathrm{v}$ Evropi so tudi $\mathrm{v}$ južnoslovanskem prostoru ustvarila okoliščine za poskus vzpostavitve novih geopolitičnih in kulturno-umetniških silnic, ki se bodo postavile nasproti oblastnim silam militarizma in kapitala, sintentiziranih $\mathrm{v}$ podobi Zahoda. $\mathrm{V}$ južnoslovanskem prostoru, kjer je bilo iskanje lastne identitete od nekdaj problematično in brez jasne kulturno-zgodovinske opore, se ta iskanja usmerijo tudi $\mathrm{v}$ odkrivanje lastnih korenin in nacionalnega. Natalija Zlidnjeva vidi v zenitizmu karakteristično balkansko sliko sveta, ki ga v veliki meri označuje "mejnost kot princip«, torej raznorodne, avtonomne komponente, ki oblikujejo vitalističen in primitivističen koncept barbarogenija (glej Zlidnjeva, »El Lissitzky«).

Micić se v svojih delih zavzema za stanje nenehnega prerajanja, ki ga dosega s stalnim sprevračanjem pozicij moči, kar predstavlja njegovo strategijo osvobajanja, pa tudi proizvajanja resnice. $V$ času monarhistične oblasti je bil Micić obtožen marksizma, kasneje, v času socialistične skupne države, pa je propagiral srbstvo in monarhiji zameril propagiranje jugoslovanstva. Lahko sklenemo, da ne glede na tovrstne obtožbe Micić pravzaprav zavzema ambivalentno stališče anarhizma, ki ne pomeni nihilizma ali destrukcije, temveč "gradi na kritiki vsega obstoječega" (Vodovnik, Anarhija 53) in sprevračanju obstoječih podob in vrednot. Micić je militanten, vendar ta militantnost ne pomeni nasilja: »Dejansko militantnost ne gre enačiti z nasiljem, prav tako kot anarhizma ni mogoče povezati z uničevanjem, če že, potem gre za uničevanje starih (napačnih) predsodkov, kar pa je najbolj konstruktivno delo, ki ga je mogoče opraviti« (25). Evrope tukaj ni treba razumeti kot geopolitične, temveč kot metafizično strukturo, kot idejo, podobo, ki se jo da "metafizično" uničiti. "[A]narhisti pojmujejo človeka, človeško naravo in družbo na osnovi koncepta natura naturans (v filozofskem smislu 'kot stvari lahko postanejo'), in ne na osnovi natura naturata (v zgodovinskem smislu, 'kot stvari so ali kot so to postale')«(53). Podobno kot anarhizem tudi zenitizem nosi v sebi princip eksaltacije oziroma vzne- 
senosti: aktualno stanje človeka ga zanima predvsem zato, ker v človeku vidi potencial za to, kar bi človek lahko postal. Prav zato je Nietzsche, ki prek konceptualnega lika Zaratustre vzpostavi resnično kritiko evropskega nihilizma in zahodne kulture, temeljna referenca za razumevanje Micićeve ideje Barbarogenija: človek je tisto, kar mora biti preseženo.

\section{LITERATURA}

Delak, Ferdo. »Mi«. Tank 1.3 (1927): 69.

Delak, Ferdo. "Mladina, podaj se v borbo«. Tank 1.1/2 (1927): 5.

Dović, Marijan. »Od autarhije do 'varvarskog' kosmopolitizma: rani avangardni pokreti u jugoslovenskoj umetnosti (1914 - 1929)«. Avangarda: od dade do nadrealizma. Zbornik radova. Ur. Bojan Jović, Jelena Novaković in Predrag Todorović. Beograd: Institut za književnost i umetnost, Muzej savremene umetnosti, 2015. 41-53.

Droit, Roger-Pol. Généalogie des barbares. Pariz: Odile Jacob, 2007.

Glišić, Iva, in Tijana Vujošević. "I am Barbarogenious: Yugoslav Zenitism of the 1920s and the Limits of Performativity". Slavic and East European Journal 60.4 (2016): 718-743.

Golubović, Vida. "Dopisovanje v zvezi z revijo tank. Černigoj - Delak - Micić«. Tank: Reprint izdaje iz leta 1927. Ljubljana: Mladinska knjiga, 1987. 96-113.

Golubović, Vida. "Pogovor«. Barbarogenije Decivilizator. Ljubomir Micić. Beograd: Filip Višnjić, 1993. 160-171.

Gurianova, Nina. The Aesthetics of Anarchy: Art and Ideology in the Early Russian AvantGarde. Berkeley; Los Angeles; London: University of California Press, 2012.

Krečič, Peter. Slovenski konstruktivizem in njegovi evropski okviri. Maribor: Založba Obzorja, 1989.

Kosovel, Srečko. Zbrano delo. Vol. 2, 3. Ur. Anton Ocvirk. Ljubljana: DZS. 1946-77.

Kralj, Lado. »'Jaz sem barbar' Barbarstvo kot motiv in ideologija v avantgardistični literaturi.« Primerjalna književnost 11.1 (1988): 29-41.

Lakoff, George, in Mark Johnson. Metaphors We Live By. Chicago: University of Chicago Press, 1980.

Micić, Ljubomir. Barbarogenije Decivilizator. Beograd: Filip Višnjić, 1993.

Micić, Ljubomir. »Čovek i umetnost«. Zenit 1 (1921): 1-2.

Micić, Ljubomir. "Duh Zenitizma«. Zenit 7 (1921): 3-5.

Micić, Ljubomir. »Delo Zenitizma«. Zenit 8 (1921): 2-3.

Micić, Ljubomir. "Iz dosijea o knjizi 'Aeroplan bez motora' Ljubomira Micića». Zli volšebnici. Polemike i pamfleti u srpskoj književnosti 1917-1929. Ur. Gojko Tešić. Beograd: Slovo Ljubve, Beogradska knjiga, 1983. 430-453.

Micić, Ljubomir. "Manifest srbijanstva». Daj nam Bože municije: Srpska avangarda na braniku otadžbine. Ur. Nikola Marinković. Beograd: Dinex, 2013. 111-129.

Micić, Ljubomir. »Papiga i monopol 'hrvatska kultura'«. Zenit 24 (1923): 1-2.

Pageaux, Daniel Henri. "Uvod v imagologijo«. Podoba tujega v slovenski književnosti. Podoba Slovenije in Slovencev v tuji književnosti (imagološko berilo). Ur. Tone Smolej. Ljubljana: Filozofska fakulteta, 2002. 9-20.

Pauly, Tzvetomila. »Nation, Tradition and Regionalism in The Avant-Garde Magazine Zenith«. Splet. 26. 5. 2020. <https://www.academia.edu/5026277/Nation_and_ Tradition_in_the_Avant_Garde_Magazine_Zenith> 
Poljanski, Branko V. »Zakonik države Dada-Jok«. Dada-Jok (1922): 3-4.

Sekeruš, Pavle. "Predstave o Drugem v francoski kulturi prve polovice 19. stoletja: razprava o južnih Slovanih". Podoba tujega v slovenski književnosti. Podoba Slovenije in Slovencev v tuji književnosti (imagološko berilo). Ur. Tone Smolej. Ljubljana: Filozofska fakulteta, 2002. 193-206.

Subotić, Irina. "Zenitism / Futurism: similarities and differences". International Yearbook of Futurism Studies. Special Issue: Futurism in Eastern and Central Europe. Vol. 1. Berlin: De Gruyter, 2011. 201-230.

Subotić, Irina. "Zenit, Zenitism and Ljubomir Micić«. Hendrik Nicolaas Werkman: Kunst is overal. Ur. Doeke Sijens in Mariëtta Jansen. Groningen: Groninger Museum, 2015. 56-69.

Subotić, Irina. »Pregled zaostavštine Ljubomira Micića«. Ljetopis Srpskog kulturnog društva Prosvjeta XX. Ur. Čedomir Višnjić. Zagreb: SKD Prosvjeta, 2015. 240-244.

Subotić, Irina. „Odblesci ruske avangarde u jugoslovenskom zenitizmu«. Arte media. Splet. 26.5.2020.<http://www.arte.rs/sr/umetnici/teoreticari/irina_subotic-3972/ tekstovi/odblesci_ruske_avangarde_u_jugoslovenskom_zenitizmu-1292/>

Šuvaković, Miško. "Impossible Histories«. Impossible Histories. Historic AvantGardes, Neo-Avant-Gardes, and Post-Avant-Gardes in Yugoslavia, 1918-1991. Ur. Dubravka Djurić in Miško Šuvaković. Cambridge: MIT Press, 2006. 2-35.

Todorov, Tzvetan. On Human Diversity: Nationalism, Racism and Exoticism in French Thought. Cambridge: Harvard University Press, 1993.

Todorova, Maria. Imagining the Balkans. Oxford: Oxford University Press, 2009.

Vodovnik, Žiga. Anarhija vsakdanjega življenja. Ljubljana: Založba Sophia, 2010.

Vodovnik, Žiga. "Balkanizovati Evropu!«. Zeničke sveske 11 (2010): 64-78.

Vrečko, Janez. "Barbarogenij, barbarsko in fašizem». Primerjalna književnost 35.5 (2012): 261-270.

Zlidnjeva, Natalija. „El Lissitzky kao ogledalo zenitizma«. Srpska avangarda u periodici. Ur. Vida Golubović in Siniša Tutnjević. Beograd: Matica srpska/Institut za književnost i umetnost, 1996. 425-430. 


\section{Zenithist Concept of a Barbarogenius as a Critique of the Western European Culture}

Keywords: Yugoslav literature / literary avant-garde / zenitism / Micić, Ljubomir / imagology / Europe / the Balkans / cultural identity

The article presents the image of a Balkan man, barbarogenius, as conceived by one of the central representatives of the Yugoslav avant-garde, Ljubomir Micić (1895-1971). The concepts of barbarian-genius and balkanization/barbarization of Europe were developed in the Zenit (1921-1926) journal, and were also represented in Micićs poetry and prose (the novel Barbarogenious Decivilizer). Similar ideas can also be found in the work of Srečko Kosovel (19041926) and in the Ljubljana Tank journal (1927). This points to the formation of a specific local identity, which indicates the national context of the Yugoslav avant-garde. In this way, we can track the original thought and art-historical specifics of this avant-garde current, connected with particular socio-political events in the first decades of the twentieth century. Both internationalization/ cosmopolitanism and radical exposure of national characteristics can be seen as strategies for the transgression of identities, and for the establishment of the Balkans as a pluralistic cultural identity with its creative power within the Yugoslav avant-garde.

1.01 Izvirni znanstveni članek / Original scientific article

UDK 821.63.41.09

$82.02 " 19 "$

DOI: https://doi.org/10.3986/pkn.v43.i3.08 